[RETRACTION]ADSORPTION OF A COPPER (II) COMPLEX ON CALCIUM PHOSPHATE INTERCALATED WITH 4-AMINOBENZOIC ACID - SYNTHESIS AND ELECTROCHEMICAL INVESTIGATION

Quimica Nova, Vol. 36, No. 8, 1170-1175, 2013

Camila F. N. Silva, Fernando M. de Souza, Jéssica P. Santos, Ana Paula B. Dias, Ana Paula R. Santana, Angélica M. Lazarin*, Rosana L. Sernaglia and Elza I. S. Andreotti

Departamento de Química, Universidade Estadual de Maringá, Av. Colombo, 5790, 87020-900 Maringá - PR, Brasil

Claudio Airoldi

Instituto de Química, Universidade Estadual de Campinas, CP 6154, 13084-971 Campinas - SP, Brasil

Recebido em 14/2/13; aceito em 9/5/13; publicado na web em 17/7/13

This article has been retracted in 25/11/2014.

Reason: This article was retracted by decision of the Editors, following Química Nova publication ethics guide, in view of apparent fraudulent use of several figures from previously and posteriorly published articles by the same authors, where same trace on the figure was assigned to different conditions and/or compounds.
The publications involved are the following: Sensors and Actuators B 2002, 87, 498-505,; Journal of Membrane Science 2003, 221, 175-184; Analytica Chimica Acta 2004, 523, 89-95; The Journal of Chemical Thermodynamics 2006, 38, 130-135; Solid State Sciences 2008, 10, 1139-1144; Materials Research Bulletin 2012, 47, 15391543; Open Journal of Synthesis Theory and Applications 2013, 2 , 1-7; Thermochimica Acta 2014, 589, 107-113. 


\title{
ADSORPTION OF A COPPER (II) COMPLEX ON CALCIUM PHOSPHATE INTERCALATED WITH 4-AMINOBENZOIC ACID - SYNTHESIS AND ELECTROCHEMICAL INVESTIGATION
}

\author{
Camila F. N. Silva, Fernando M. de Souza, Jéssica P. Santos, Ana Paula B. Dias, Ana Paula R. Santana, Angélica M. \\ Lazarin*, Rosana L. Sernaglia and Elza I. S. Andreotti \\ Departamento de Química, Universidade Estadual de Maringá, Av. Colombo, 5790, 87020-900 Maringá - PR, Brasil \\ Claudio Airoldi \\ Instituto de Química, Universidade Estadual de Campinas, CP 6154, 13084-971 Campinas - SP, Brasil
}

Recebido em 14/2/13; aceito em 9/5/13; publicado na web em 17/7/13

\begin{abstract}
In this study, the adsorption isotherm of copper (II) on a calcium phosphate host intercalated with 4-aminobenzoic a $\mathrm{d}$ in an ethanol solution was investigated. This gave a maximum adsorption capacity of $1.74 \mathrm{mmol} \mathrm{g}{ }^{-1}$. The material was incorporated $\mathrm{h}$ a carbonpaste electrode, and its electrochemical properties were investigated. However, for a dopamine solution, e an current increased owing to the electrocatalytic oxidation. The electrode presented the same response for at leact 150 succ sive measurements, showing good repeatability. The modified electrode is very stable and reproducible. The electro c sensor, s su. essfully applied for dopamine determination in pharmaceutical preparations.
\end{abstract}

Keywords: calcium phosphate; intercalation; carbon-paste electrode.

\section{INTRODUCTION}

The usability of chemically modified electrodes has been extensively investigated because of not only the advantages offered by these devices ${ }^{1,2}$ but also their ability to improve selectivity and sensitivi Selectivity and sensitivity are the key properties for detecting elec troactive species dispersed in various media. ${ }^{3}$ From the wpoint of applicability, most of the immobilized active center are a le to mediate the electron transfer processes and are usefu or fabri electrochemical sensors. ${ }^{4-7}$

The effectiveness of such chemical modific on involve. ovalent bonding within a given matrix, thus enabling dson ion, interca ation, electrodeposition, or mixing for condur $\mathrm{ng}$ particle. vith a specific reagent for preparing electrodes fror carbon paste. ${ }^{8-11}$

Owing to the significance of onitor g biochemical and biomedical applications, the developme. 1 new $\mathrm{r}$ thods of analysis employing electrochemical nso basec. $n$ c on paste, ${ }^{12-14}$ carbon fiber, ${ }^{15,16}$ glassy carbon, ${ }^{17}$ thick-f arbol. ${ }^{9,20}$ and polymer-coated electrodes $^{21,22}$ has been at. ti resea. it attention.

A large number of inorg ic compounds are suitable as hosts for such an investigation, partic arly a class of crystalline layered phosphate compounds presents high ion exchange capacity and conductivity. ${ }^{23}$ Owing to these characteristics, a crystalline layered phosphate compound can be used as a matrix for immobilization of electroactive species. ${ }^{24}$

This investigation focuses on the electrochemical behavior of copper (II) as it is adsorbed on 4-aminobenzoic acid intercalated calcium phosphate. This newly synthesized compound was first used to prepare a carbon-paste electrode. The resulting material was used to test dopamine oxidation. This active molecule was chosen because it is one of the most significant catecholamines and plays a very important role in the functioning of the central nervous system, as well as the cardiovascular, renal, and hormonal systems. Its concentration in extracellular fluid is less than that of ascorbic acid (AA). A deficiency of dopamine in the central nervous system can cause serious abnormalities such as schizophrenia and Parkinson's disease.

*e-mail: amlazarin2@uem.br
Co antly, the a lysis of these compounds in real-world biologiI samples and the identification of neurotransmission changes are iportant. $\mathrm{Nc}$ rotransmission changes may correlate to the behavioral st. of an a mal and are obvious targets of enormous importance in the ne of neurochemical studies. Therefore, the quick deter-

ation of dopamine in vitro and in living creatures has attracted considerable attention..$^{25-28}$ This paper proposes an electrochemical procedure employing an innovative, stable inorganic support.

\section{EXPERIMENTAL}

\section{Synthesis of calcium phosphate}

Calcium phosphate $(\mathrm{CaP})$ was synthesized by slowly adding a dilute solution of calcium chloride dehydrated to a $1.50 \mathrm{~mol} \mathrm{dm}^{-3}$ dibasic ammonium phosphate solution. The mixture was heated to 360 $\mathrm{K}$. The resulting suspension was stirred for $1 \mathrm{~h}$ as the solid began to settle. The precipitate was filtered and dried at $320 \mathrm{~K}$. Finally, the resulting compound was heated at $440 \mathrm{~K}$ for $48 \mathrm{~h}$ to eliminate ammonia.

\section{Intercalation procedure}

About $50 \mathrm{mg}$ of $\mathrm{CaP}$ was immersed in $20.0 \mathrm{~cm}^{3}$ of $1.0 \times 10^{-3}$ mol dm${ }^{-3}$ aqueous 4-aminobenzoic acid (PABA), and the suspension was shaken in an orbital mechanical stirrer for $1 \mathrm{~h}$. This stir time was determined for a constant concentration of PABA after varying the solid/solution ratios and contact time up to $12 \mathrm{~h}$ in order to obtain the best intercalation condition for this guest molecule. The resulting solid was filtered, washed with doubly distilled water, and dried at $323 \mathrm{~K}$

\section{Characterization}

Calcium and phosphorus ${ }^{29,30}$ elemental analyses were performed by atomic absorption spectroscopy using a Perkin Elmer atomic absorption spectrometer, model 5100, and other spectrophotometric methods using a Shimadzu spectrophotometer, model MultiSpec-1501.

The amount of PABA intercalated into calcium phosphate 
was determined by nitrogen elemental analysis on a Perkin-Elmer Analyzer 2400 series H CHNS/O apparatus.

$\mathrm{X}$-ray diffraction patterns were obtained with nickel-filtered $\mathrm{CuK} \alpha(0.154 \mathrm{~nm})$ radiation in the range $2-65^{\circ}$ at a speed of $0.033^{\circ}$ $\mathrm{s}^{-1}$ and a step of $0.050^{\circ}$ on a Shimadzu XD3-A diffractometer $(30 / 20$ $\mathrm{kV} / \mathrm{mA}$ )

Infrared spectra of the samples were collected on a Perkin-Elmer FTIR spectrophotometer, model 1600 , using pressed $\mathrm{KBr}$ pellets in the 4000-400 $\mathrm{cm}^{-1}$ range at a resolution of $4 \mathrm{~cm}^{-1}$.

Copper (II) concentration in the supernatant was measured by atomic absorption spectroscopy using a Perkin-Elmer atomic spectrometer, model 5100.

The UV-Vis spectra of the CaP/PABA with adsorbed copper (II) were obtained in Nujol on a Beckman DU 640 spectrophotometer.

\section{Adsorption isotherms}

Using a batchwise method, the adsorption isotherm of $\mathrm{CuCl}_{2}$ in the ethanol solution was obtained. For each isotherm, a series of samples containing $100 \mathrm{mg}$ of $\mathrm{CaP}$ intercalated with PABA was shaken for $3 \mathrm{~h}$ (as previously established) ${ }^{31}$ in an orbital bath with various concentrations of the metal halide at a constant temperature of $298 \pm$ $1 \mathrm{~K}$. The concentration of copper in the solution at equilibrium with the solid phase was determined by atomic adsorption spectrometry. The amount of copper adsorbed $n_{\mathrm{f}}$ was determined by applying the equation: $n_{f}=\left(n_{i}-n_{s}\right) / m$, where $m$ is the mass of the adsorbent, and $n_{i}$ and $n_{s}$ are the initial and equilibrium amounts of the number of moles of copper cations in the solution phase, respectively.

\section{Electrochemical measurements}

The modified carbon-paste electrode was prepared by mix $\mathrm{gg}$ ? $\mathrm{mg}$ of the intercalated/adsorbed copper (II) calcium hate, $3 \mathrm{mg}$ of graphite (Fluka), and a drop of mineral oil $.0 \times 10 \mathrm{sm}^{3}$ ). he paste was deposited into a cavity on the surfac of a atinu disk, which was fused at the end of a glass tub with an ner diameter of $3 \mathrm{~mm}$. This proportion produced a gr a ssponse in preliminary test after a detailed study of the paste compo tion. This electrode is referred to as $\mathrm{CaP} / \mathrm{PABA} / \mathrm{Cu}(\mathrm{II}$, ereafter.

Electrochemical measur aents y performed using the $\mathrm{CaP} /$ $\mathrm{PABA} / \mathrm{Cu}$ (II) electrode as the ork "g electrode, a saturated calomel (SCE) as the reference rode, d a pl num wire as the auxiliary electrode. The ele ochen cal pro des of copper (II) adsorbed on calcium phosp te int car d with 4-aminobenzoic acid were studied by means or lic voltammetry (CV) using a PAR 273A $(E G \& G)$ potentiostat/ga $a$ nostat. The experiments were conducted in a $0.10 \mathrm{~mol} \mathrm{dm}^{-3}$ of phosphate buffer electrolyte solution under a pure argon atmosphere. The $\mathrm{pH}$ was adjusted by adding $\mathrm{HCl}$ or $\mathrm{NaOH}$ to the solution. Different supporting electrolytes were also tested. The response of the electrode used for dopamine determination was evaluated by an amperometric technique in a $0.010 \mathrm{~mol} \mathrm{dm}^{-3}$ standard aqueous solution. Fixed volumes $\left(50 \mu \mathrm{dm}^{3}\right)$ of the standard dopamine solution were added successively to an electrochemical cell containing a $0.10 \mathrm{~mol} \mathrm{dm}^{-3}$ phosphate buffer electrolyte solution, in order to obtain a total volume of $1.0 \mathrm{~cm}^{3}$. The calibration plot obtained from this experiment was used to determine the dopamine concentration in commercial samples (Revivan) and a standard reference material (dopamine hydrochloride injection (DHI)). The commercial and reference samples were made by dissolving $2.0 \mathrm{~cm}^{3}$ of Revivan and DHI in doubly distilled, degassed water and diluted to $10.0 \mathrm{~cm}^{3}$ (solution A and solution B), respectively. The chronoamperometric response was obtained by adding solution $\mathrm{A}$ or $\mathrm{B}$ to a cell filled with a $10.0 \mathrm{~cm}^{3}$ phosphate buffer electrolyte solution in increments of
$200 \mu \mathrm{L}$. All chronoamperometric measurements were performed at $\mathrm{pH} 7.2$ under a pure argon atmosphere.

\section{RESULTS AND DISCUSSION}

\section{Characterizations}

Elemental analysis of the synthesized compound indicated that the compositions of calcium and phosphorous were 26.3 and $17.2 \%$, respectively. The values are very close to the expected compositions of 26.5 and $17.1 \%$ (respectively) for the proposed formula $\mathrm{Ca}\left(\mathrm{H}_{2} \mathrm{PO}_{4}\right)_{2}$. On the basis of these values, the corresponding molar amounts of these elements were calculated to obtain a phosphorus to calcium ratio of $2: 1$. The quantity of PABA intercalated into $\mathrm{CaP}$ was determined through nitrogen content analysis. composition of $4.2 \%$ of nitrogen atoms within the guest molecule con sponds to $3.0 \mathrm{mmol} \mathrm{g}^{-1}$.

The layered structural volalline calcium phosphate shows an interlayer distan that is $u_{1}$-ndent on the size of the cation or the mole alia d into the host. An X-ray powder diffractogram is a ood tool fo obs ving the change in the interlayer distance in order , examine $\mathrm{t}$, uptake process.

The por ' $\mathrm{r}$ X vy diffract on patterns of the synthetic compound and the orm erca. sth 4-aminobenzoic acid are shown in Figv 1 . Sharp po 's signify the crystallinity of the resulting solids. $\mathrm{T}^{\prime}$ int e peak at $\angle \mathrm{J}=12.8^{\circ}$ corresponds to an interlayer distance of $712 \mathrm{pm}$ \& the original lamellar compound, ${ }^{32,33}$ as shown in Figure 1a. As expectc. the interlayer distance increases when this inorganic suppo is suspended in the aqueous solution containing dissolved 4-amir benzoic acid molecules. The result is a sharp peak at $2 \theta=$ $5.6^{\circ}$ at corresponds to an interlayer distance of $1578 \mathrm{pm}$, which is nearly double the value of the original lamellar compound, as shown in Figure 1b.

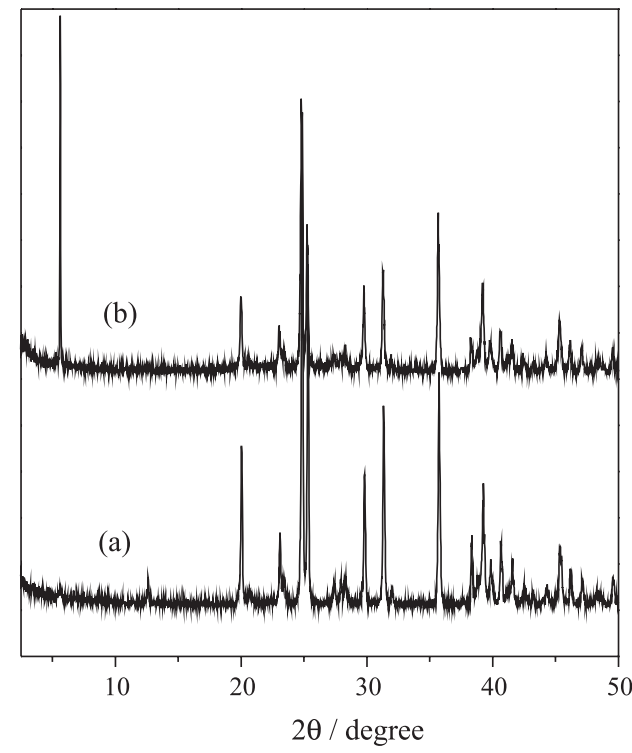

Figure 1. X-ray diffraction patterns of calcium phosphate (a) and (b) its 4-aminobenzoic acid form

The $\mathrm{OH}$ groups of the phosphate in the lamellar calcium phosphate exhibit stretching at $3400 \mathrm{~cm}^{-1}$ and weak deformation at $1630 \mathrm{~cm}^{-1}$ bands in the infrared spectrum. The intense characteristic stretching bands for phosphate groups are located at 1033 and $1010 \mathrm{~cm}^{-1}{ }^{32}$ However, after intercalation with 4-aminobenzoic acid, the bands attributed to $\mathrm{OH}$ vibrations remain in the spectrum and decrease in intensity. This mainly occurs to the deformation band, as observed for 
other systems. ${ }^{7,34}$ There is no clear evidence of $\mathrm{NH}$ vibration bands at 3580 and $3077 \mathrm{~cm}^{-1}$

\section{Adsorption of copper}

Adsorption isotherms for $\mathrm{Cu}^{2+}$ cations in an ethanol solution were investigated in relation to the intercalated crystalline lamellar compound. Initially, our investigation demonstrated that the original matrix without PABA does not adsorb this cation. The adsorption isotherm of the CaP/PABA system is shown in Figure 2. The amount of copper cations on the host surface was found to be $1.68 \mathrm{mmol}$ per gram of the solid. The electronic absorption spectrum of the copper (II) complexed within the intercalated compound is shown in Figure 3. The observed spectrum is similar to that observed for square planar copper (II) complexes on chemically modified silica gels containing pendant chains with amine groups, ${ }^{35}$ as well as on chemically modified cellulose acetate membranes. ${ }^{36}$ The Gaussian components of the absorption bands show a peak maxima at 550 and $640 \mathrm{~nm}$, which correspond to a complex with $\mathrm{D}_{4 \mathrm{~h}}$ local crystal field symmetry and can be assigned to the ${ }^{2} \mathrm{~B}_{1 \mathrm{~g}} \rightarrow{ }^{2} \mathrm{E}_{\mathrm{g}}$ and ${ }^{2} \mathrm{~B}_{1 \mathrm{~g}} \rightarrow{ }^{2} \mathrm{~A}_{1 \mathrm{~g}},{ }^{2} \mathrm{~B}_{2 \mathrm{~g}}$ d-d transitions, ${ }^{37-40}$ respectively.

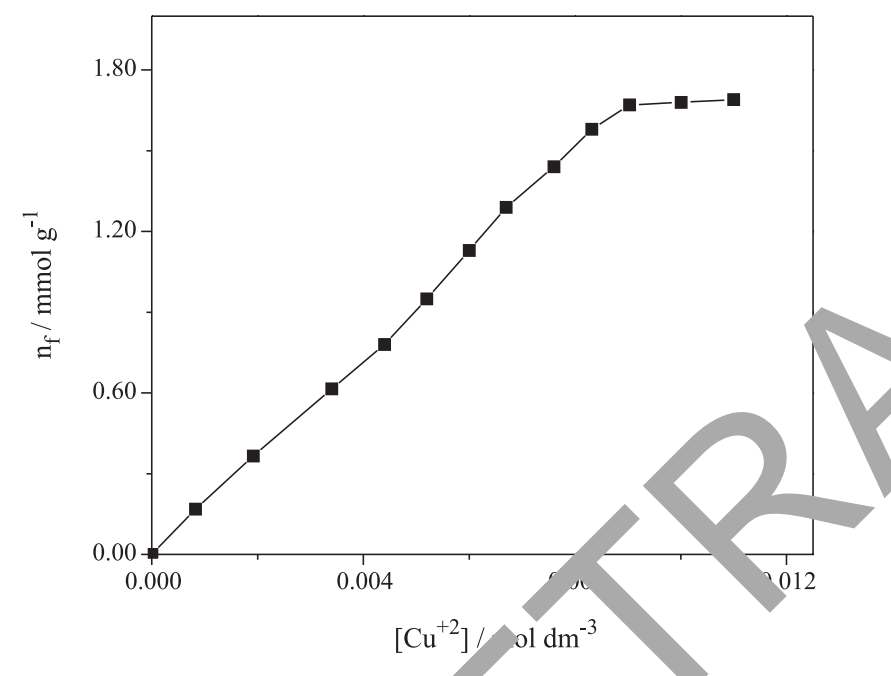

Figure 2. Isotherm of copper complex on on 4 ninobenzoic acid in CaP compound

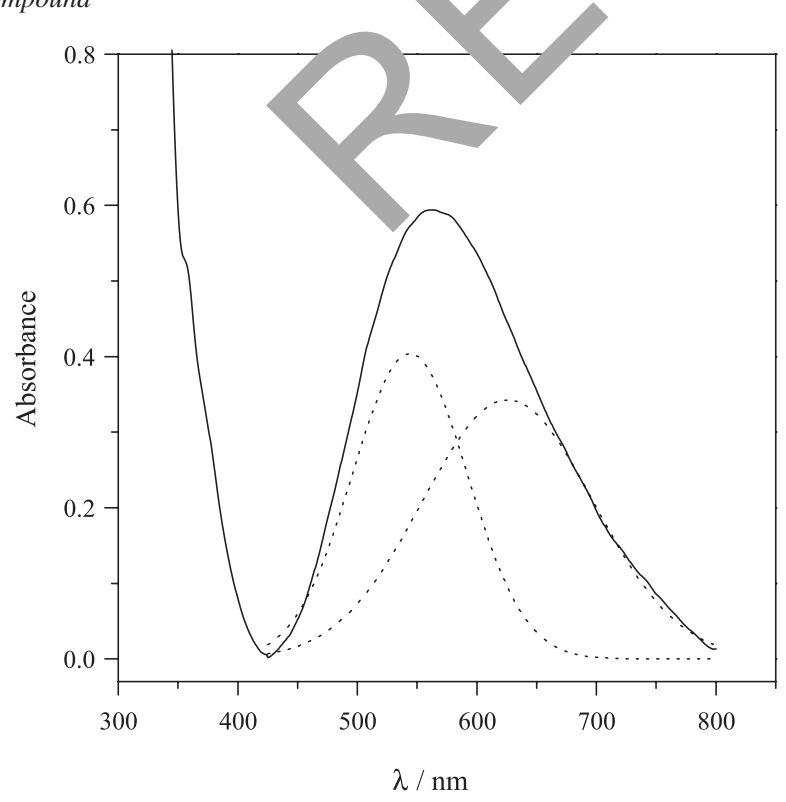

Figure 3. Electronic transition spectrum of $\mathrm{CaP} / \mathrm{PABA} / \mathrm{Cu}(\mathrm{II})$

\section{Electrochemical studies}

Cyclic voltammetry (CV) was performed using a carbon-paste electrode modified with the material. No current peaks are observed for an electrode modified with only calcium phosphate intercalated with 4-aminobenzoic acid. However, CV curves for carbon-paste electrodes prepared with CaP/PABA with complexed copper (II) were obtained. In this case, a current peak is observed with a midpoint potential at $\mathrm{E}_{\mathrm{m}}=0.16 \mathrm{~V}$, where $\mathrm{E}_{\mathrm{m}}=\left(\mathrm{E}_{\mathrm{pa}}+\mathrm{E}_{\mathrm{pc}}\right) / 2$, and $\mathrm{E}_{\mathrm{pa}}$ and $\mathrm{E}_{\mathrm{pc}}$ are the observed anodic and cathodic peak potentials, respectively. This low midpoint and an anodic peak potential near zero are very important for sensor/biosensor development. In comparison with earlier results, this wave can be attributed to the process of transfer of an electron in the coupling, ${ }^{41-43}$ as shown in equation 1 :

$\left[\mathrm{Cu}^{\mathrm{II}}(\mathrm{CaP} / \mathrm{PABA})_{4}\right]+\mathrm{s}^{+}+\mathrm{e}^{-} \rightleftharpoons\left[\mathrm{sCu}^{\mathrm{I}}(\mathrm{C} / \mathrm{PABA})_{4}\right]$,

where the supporting electrolyte the rcu process, namely $\mathrm{s}^{+}$, must diffuse into or $\mathrm{m}$ of surface of the structured complex.

Cycling the potenti I several tin s helped in verifying the stability of the electr ' 1 . 1. peak cur ent intensities do not decrease, indicating tha ne co lex allo strongly adheres to the nobenzoic dintercala calcium phosphate and is not released to the solu on $\mathrm{ps}_{\mathrm{L}}$ e under th operating conditions.

Cuclic voltan ograms obtained at different scan rates indicate th $c$ the value of $\Delta \mathrm{E}_{\mathrm{p}} \Delta \mathrm{E}_{\mathrm{p}}=\mathrm{E}_{\mathrm{pa}}-\mathrm{E}_{\mathrm{pc}}$ ) increases at higher rates. This sult sugge $s$ that the electron transfer on the electrode surface is $n$ t sufficient fast. This is a consequence of the high resistance of the atrix ne correlation of the peak currents, $\mathrm{I}_{\mathrm{pa}}$ and $\mathrm{I}_{\mathrm{pc}}$, against $1 / 2$ ( $v$ is the scan rate) is linear, as shown in Figure 4. This is similar o a ffusion controlled process. Because the electroactive species strongly adheres to the matrix, the mechanism may be explained by the transport of an ion from the supporting electrolyte on the electrode surface for charge compensation. ${ }^{44}$ The supporting electrolytes studied here (phosphate buffer and $\mathrm{KCl}$ ) did not have any significant influence on $\mathrm{E}_{\mathrm{m}}$, whose values varied between 0.16 and $0.17 \mathrm{~V}$. These results indicate that the supporting electrolytes are not interacting with the matrix surface and produce no significant change in the midpoint potential. It was also observed that the ion could compensate the charge irrespective of the hydrated radius. A similar behavior was observed in osmium-complex-modified electrodes. ${ }^{45}$

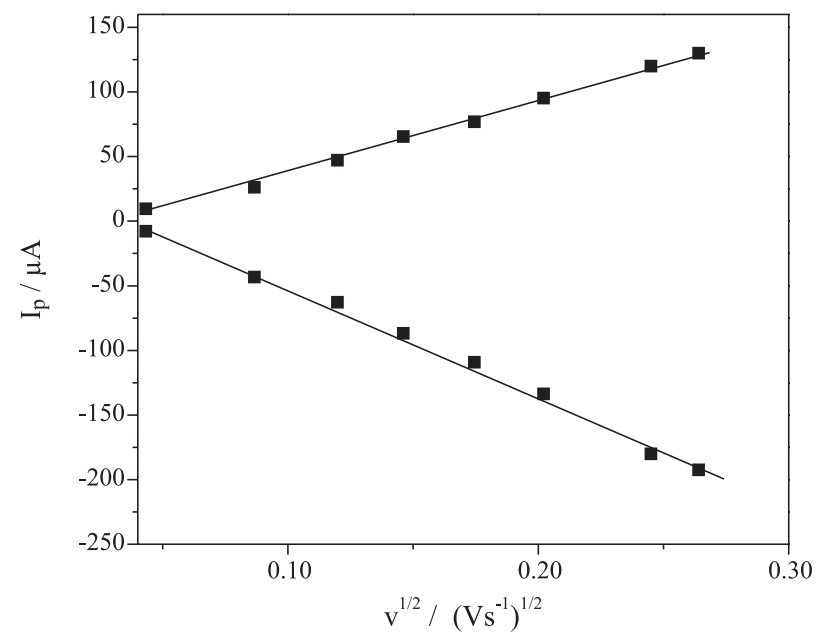

Figure 4. Anodic $\left(I_{p a}\right)$ and cathodic $\left(I_{p c}\right)$ current peaks against square root of the scan rate $v^{I / 2}$ for a CaP/PABA/Cu(II) electrode in $0.10 \mathrm{~mol} \mathrm{dm}^{-3}$ phosphate buffer at $\mathrm{pH} 7.2$ 


\section{Electrocatalytic oxidation}

Dopamine (DA) oxidation on the surface of the $\mathrm{CaP} / \mathrm{PABA} / \mathrm{Cu}$ (II) electrode is shown in Figure 5. The CV curves in the presence of 2.5 $\times 10^{-5} \mathrm{~mol} \mathrm{dm}^{-3}$ dopamine solution at $\mathrm{pH} 7.2$ show a considerable increase in the anodic peak current. The cathodic peak can be associated with the stronger interaction between the copper complex present in the electrode surface and the matrix surface. ${ }^{46}$ Alternatively, the cathodic peak can be associated with the products of the dopamine oxidation. This was verified by using a glassy carbon electrode in the presence of the dopamine solution. A similar behavior was observed in other systems. ${ }^{47}$ Dopamine electrochemical oxidation has been investigated mostly on carbon-paste electrodes, ${ }^{48-50}$ and the complete effect corresponds to a two-electron process, followed by a two-proton process, as represented in equation 2 . The reaction indicates the oxidation of DA into DA $o$-quinone (DAQ).${ }^{51}$
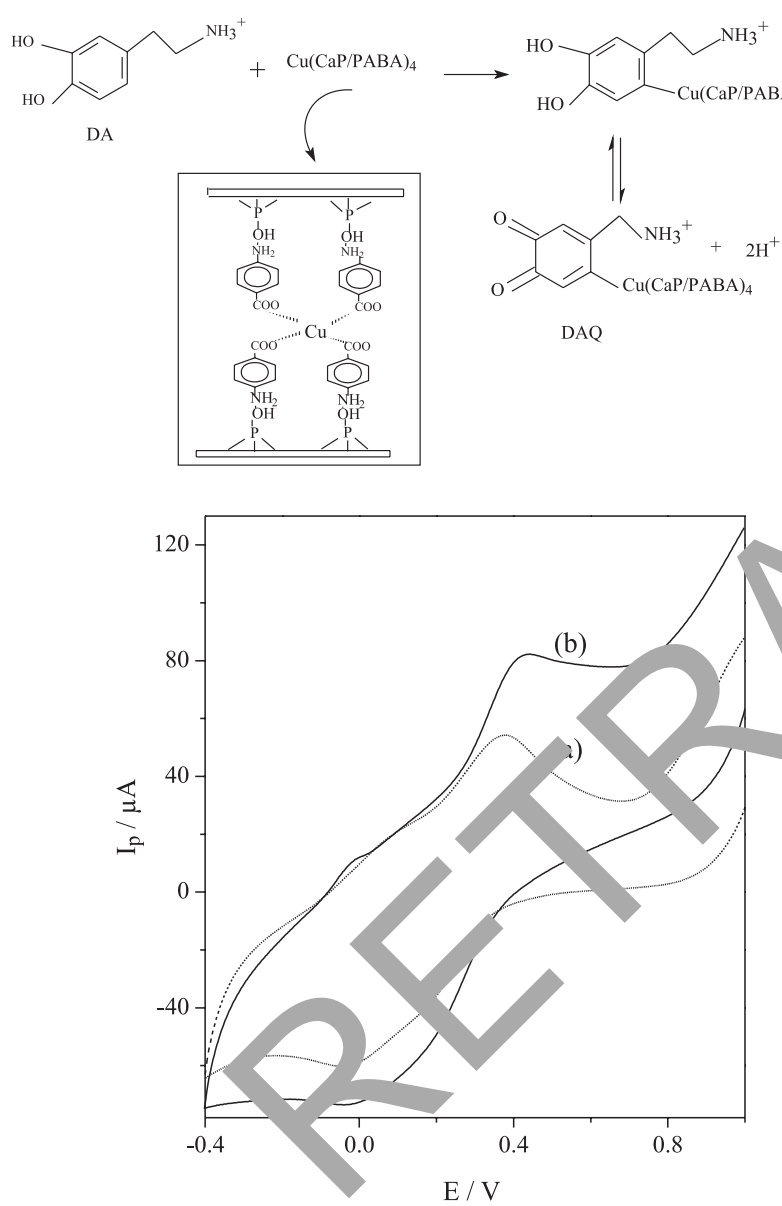

Figure 5. Cyclic voltammogram curves for the CaP/PABA/Cu(II) electrode in the (a) absence and (b) presence of dopamine $\left(0.10 \mathrm{~mol} \mathrm{dm}^{-3}\right.$ phosphate buffer) at $\mathrm{pH}$ 7.2. Scan rate of $20 \mathrm{mVs}^{-1}$

\section{Chronoamperometry}

To assess the possibility of using the electrode, which is fabricated from adsorbed copper in 4-aminobenzoic acid intercalated calcium phosphate, as a sensor for DA, chronoamperometric experiments were conducted. First, amperometric studies were conducted in order to determine the best potential to be applied. The potential was chosen by measuring the intensities of catalytic currents at $298 \mathrm{~K}$ for a solution containing $1.0 \times 10^{-3} \mathrm{~mol} \mathrm{dm}^{-3} \mathrm{DA}$ at $\mathrm{pH}$ 7.2. The plot of the current peak intensities against the different potentials (figure not shown) showed that the catalytic currents remain constant at $0.38 \mathrm{~V}$.

(2)
The effect of solution $\mathrm{pH}$ on the response of DA was investigated (data not shown). Normally, the solution $\mathrm{pH}$ influences the oxidation of dopamine. ${ }^{52}$ In the present case, the CaP/PABA/Cu(II) electrode was immersed in a $0.10 \mathrm{~mol} \mathrm{dm}^{-3}$ phosphate buffer solution with [DA] $=1.0 \times 10^{-3} \mathrm{~mol} \mathrm{dm}^{-3}$. The $\mathrm{pH}$ was varied between 3.0 and 8.0 . The current practically remained constant throughout the interval. While at a $\mathrm{pH}$ level lower than 4.5 , a considerable decrease in the response was detected. Therefore, the difference in the $\mathrm{pH}$ dependence of DA means that DA oxidation uses different proton and electron-transfer mechanisms. According to the Nernst equation, the slope of -55.7 $\mathrm{mV} / \mathrm{pH}$ unit reveals that the proportion of the electrons and protons involved in the reactions is $1: 1$. Since DA oxidation is a two-electron process, the number of protons involved is also expected to be two.

Figure 6 shows the amperometric curve obtained by successively adding $50 \mu \mathrm{dm}^{3}$ of a $0.010 \mathrm{~mol} \mathrm{~d}_{1}{ }^{3} \mathrm{DA}$ solution with the phosphate buffer at $\mathrm{pH} 7.2$ into an electroche ical cell fixed at $\mathrm{E}_{\mathrm{pa}}=0.38 \mathrm{~V}$. The response time is low a $1.5 \mathrm{~s} . r$ the current to achieve the maximum value, as shown in he Figur nset.

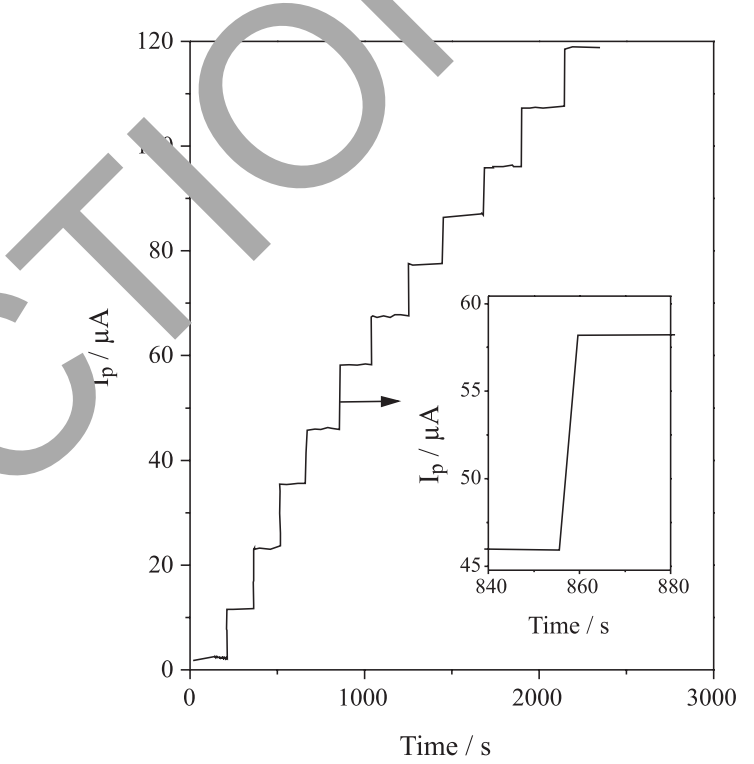

Figure 6. Chronoamperogram obtained with $\mathrm{CaP} / \mathrm{PABA} / \mathrm{Cu}(\mathrm{II})$ electrode in $0.10 \mathrm{~mol} \mathrm{dm}^{-3}$ phosphate buffer solution at $\mathrm{pH} 7.2$ and an applied potential of $0.38 \mathrm{~V}$. Successive additions of $50 \mu \mathrm{dm}^{3}$ of a $0.010 \mathrm{~mol} \mathrm{dm^{-3 }} \mathrm{DA}$ solution. The inset figure represents the peak current against time

The plot of the current peak against dopamine concentration is shown in Figure 7. A linear correlation with the concentration of the acid between $1.1 \times 10^{-6}$ to $7.4 \times 10^{-4} \mathrm{~mol} \mathrm{dm}^{-3}$ is observed with a detection limit of $1.1 \times 10^{-6} \mathrm{~mol} \mathrm{dm} \mathrm{dm}^{-3}$. The proposed electrode presents a higher detection limit for DA, which makes the sensor very attractive for determination of dopamine in drugs in comparison with other modified electrodes. ${ }^{47,53,54}$

The performance of electrode over a period of six months with measurements of the oxidation peak currents for a $0.010 \mathrm{~mol} \mathrm{dm}^{-3}$ DA solution in a $0.10 \mathrm{~mol} \mathrm{dm}^{-3}$ phosphate buffer solution ( $\left.\mathrm{pH} 7.2\right)$ was observed on each consecutive day. This serves as an indicator of the stability of the modified electrode toward dopamine. The electrode was used daily. The experimental results indicated that the current responses showed a relative standard deviation of $3.77 \%$, suggesting that the modified electrode possesses good stability.

The reproducibility of the electrode was investigated. Repetitive measurements were performed in $0.010 \mathrm{~mol} \mathrm{dm}^{-3} \mathrm{DA}$. The results of 150 successive measurements show a relative standard deviation of $1.07 \%$. Thus, the modified electrode is very stable and good reproducibility is observed. 


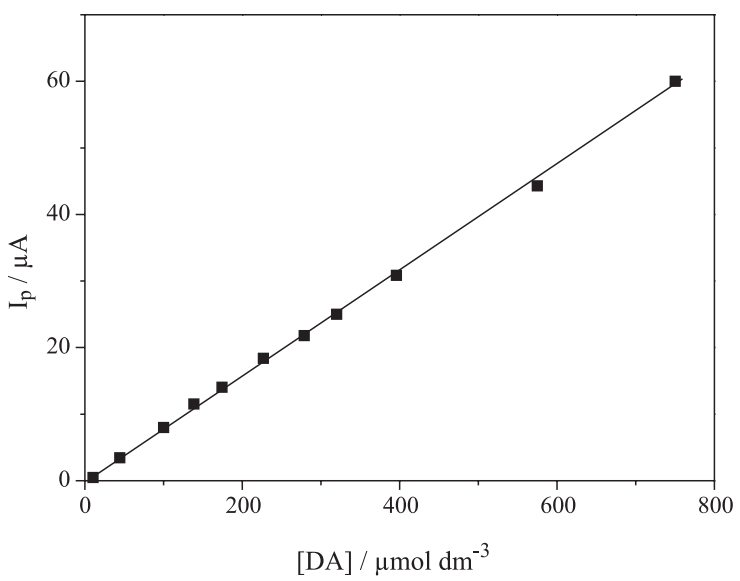

Figure 7. Plot of anodic peak current $\left(I_{p a}\right)$ against dopamine concentration in a $0.10 \mathrm{~mol} \mathrm{dm^{-3 }}$ phosphate buffer solution at pH 7.2. Scan rate is $20 \mathrm{mVs}^{-1}$

\section{Interference study}

The major sources of interference in dopamine determination are a few commonly coexisting species in biological fluids; this could lead to either new voltammetric peaks or an overlap with the existing ones, thereby influencing their voltammetric response. The effects of citric acid, tartaric acid, glucose, uric acid, ascorbic acid (AA), and sodium chloride $(\mathrm{NaCl})$ on the voltammetric peak response of $1.0 \times 10^{-3} \mathrm{~mol} \mathrm{dm}^{-3}$ of dopamine was examined. It was observed that 300 -fold concentrations of $\mathrm{NaCl}$, tartaric acid, and glucose, a 100fold concentration of citric acid, and 10-fold concentrations of uric acid and AA have no significant influence on the voltammetric pe response of $1.0 \times 10^{-6} \mathrm{~mol} \mathrm{dm}^{-3} \mathrm{DA}$. The peak current signal chan was below $5 \%$ in all cases.

\section{Determination of dopamine in real samples}

The result obtained from $\mathrm{CV}$ for a commer al samp. and DHI with the $\mathrm{CaP} / \mathrm{PABA} / \mathrm{Cu}(\mathrm{II})$ electrode is 5.01 16 and 5.0 +0.18 $\mathrm{mg} \mathrm{cm}{ }^{-3}$, respectively. These results are in good as ement with the label value of $5.0 \mathrm{mg} \mathrm{cm}^{-3}$, with a cr adence inter of $95 \%$ for $\mathrm{n}=10$. This indicates the feasibili of usi the electrode for DA determination in real samples.

\section{CONCLUSIONS}

The elemental analysis a obtained in this study enabled the determination of the molecula. "ormula for the crystalline lamellar $\mathrm{Ca}\left(\mathrm{H}_{2} \mathrm{PO}_{4}\right)_{2}$ compound. The expansion of the basal distance was detected by $\mathrm{X}$-ray diffraction patterns, whose lamellar structure was maintained after intercalation. The availability of the basic centers in the intercalated compound allows this material to adsorb cations from an ethanol solution at the solid/liquid interface. This is shown by the isotherms of $\mathrm{Cu}$ (II) cations.

The results obtained from the electrode containing CaP/PABA/ $\mathrm{Cu}$ (II) are very promising considering the fact that other chemical species that may have been present did not interfere with the determination. The advantages of using the proposed $\mathrm{CaP} / \mathrm{PABA} / \mathrm{Cu}$ (II) electrode have been established by our analytical procedures, and its development is simple. The electrode did not show significant changes in response after six months of use, thus showing good chemical stability. These characteristics make this material very attractive for use as a sensor for dopamine determination. The electrode showed a reasonable detection limit with the chronoamperometric technique, with the detection limit of dopamine reaching $1.1 \times 10^{-6} \mathrm{~mol} \mathrm{dm}^{-3}$.

\section{ACKNOWLEDGMENTS}

The authors are indebted to CNPq for financial support and J. A. da Silva for revising the manuscript.

\section{REFERENCES}

1. Song, S.; Clark, R. A.; Bowden, E. F.; Taylor, M. J; J. Phys. Chem. 1993, 97, 6564.

2. Edmonds, T.; Chemical Sensors, Blackie: Glasgow, 1988.

3. Yabuki, S.; Mizutani, F.; Asai, M.; Biosens. Bioelectron. 1991, 6, 311.

4. Gorton, L.; Torstensson, A.; Jaegfeld, H.; Johansson, G.; J. Electroanal. Chem. 1984, 161, 103.

5. Castellani, A. M.; Gushikem, Y.; J. Colloid Interface Sci. 2000, 230, 195.

6. Zaitseva, G.; Gushikem, Y.; Ribeiro, E. : Rosatto, S.S.; Electrochim. Acta 2002, 47, 1469.

7. Borgo, C. A.; Lazarin, A. M.; '1. Yctuators, B 2002 , $87,498$.

8. Kalcher, K.; Kauffmar J. Wa J.; Svancara, I.; Vytras, K.; Neuhold, C.; Yang, Z Electroana

9. Gorton, L.; Electroar lysis 1995, 7, 3.

10. Dias, S. L. P., 'ush m, Y.; Ri iro, E. S.; Benvenutti, E. V.; J. Electroanr Chem. $\mathbf{0 0 2}$,

11. Lazarir M.; Airola C.; Anal. Chim. Acta 2004, 523, 89.

12. Kar il-Ma. H.; Ensà, A. A.; Ensafi, H. R.; J. Braz. Chem. Soc. 20n9, 20, 880.

Raoof, J.; Ojani, ^, Chek In, F.; Hosseinzadeh, R.; Int. J. Electrochem. Sci. 200; ?, 848 .

Liu, S.; Ju H.; Biosens. Bioelectron. 2003, 19, 177.

15. Truác. Gregor, C.; Machová, M; Králová, J.; Bystron, T.; Cíz, M.; Louk, A.; Bioelectrochemistry 2007, 71, 46.

10. Hanese, C.; Buscaglia, V.; Maglia, F.; Anselmi-Tamburini, U.; J. Phys. Chem. B 2002, 106, 5859.

17. Evtugyn, G. A.; Stoikov, I. I.; Beljyakova, S. V.; Shamagsumova, R. V.; Stoikova, E. E.; Yu. A.; Zhukov, A. Yu; Antipin, I. S.; Budnikov, H. C.; Talanta 2007, 71, 1720.

18. Ensafi, A. A.; Mirmomtaz, E.; J. Electroanal. Chem. 2006, 583, 176.

19. Wang, J.; Electroanalysis 2005, 17, 7.

20. Welch, C. M.; Compton, R. G.; Anal. Bioanal. Chem. 2006, 384, 601

21. Zeng, H.; Jiang, Y.; Xie, G.; Yu, J.; Sens. Actuators, B 2007, $122,1$.

22. Lee, S.; Lee, Y.; Sawada, K.; Takao, H.; Ishida, M.; Biosens. Bioelectron. 2008, 24, 410 .

23. Clearfield, A.; Chem. Rev. 1988, 88, 125.

24. Ruan, C.; Yang, F.; Xu, J.; Lei, C.; Deng, J.; Electroanalysis 1997, 15, 11804.

25. Ramesh, P.; Suresh, G. S.; Sampath, S.; J. Electroanal. Chem. 2004, 561, 173.

26. Shankaran, D. R.; Kimura, K.; Kato, T.; Sens. Actuators, B 2003, 94, 73.

27. Wu, K.; Fei, J.; Hu, S.; Anal. Biochem. 2003, 318, 100.

28. Reis, A. P.; Tarley, C. R. T.; Maniasso, N.; Kubota, L. T.; Talanta 2005, 67, 829.

29. Poojary, D. M.; Zhang, B.; Cabeza, A.; Aranda, M. A. G.; Bruque, S.; Clearfield, A.; J. Mater. Chem. 1996, 6, 639.

30. Silva, C. F. N.; Lazarin, A. M.; Sernaglia, L. R. L.; Andreotti, E. I. S.; Mater. Res. Bull. 2012, 47, 1539.

31. Lazarin, A. M.; Ganzerli, T. A.; Sernaglia, R. L.; Andreotti, E. I. S.; Airoldi, C.; Mater. Res. Bull. 2009, 44, 2087.

32. Kim, H.-N.; Keller, S. W.; Mallouk, T. E.; Schmitt, J.; Chem. Mater. 1997, 9, 1414.

33. Airoldi, C.; Lima, C. B. A.; Solid State Sci. 2004, 6, 1245.

34. Pessôa, C. A.; Gushikem, Y.; Kubota, L. T.; Electroanalysis 1997, 10, 800.

35. Zaitsev, V. N.; Skopenko, V. V.; Trofimchuk, A. K.; Russ. J. Inorg. Chem. 1984, 29, 700. 
36. Lazarin, A. M.; Borgo, C. A.; Gushikem, Y.; J. Membr. Sci. 2003, 221, 175.

37. Romanowshi, S. M. D.; Mangrich, A. S.; Quim. Nova 2001, 5, 592.

38. Zurita, D.; Scheer, C.; Pierre, J. L.; Saint-Aman, E.; J. Chem. Soc., Dalton Trans. 1996, 4331.

39. Matovic, Z. D.; Miletec, V. D.; Samardzic, G.; Pelosi, E.; Lanelli, S.; Trifunovic, S.; Inorg. Chim. Acta 2005, 358, 3135.

40. Muresan, V.; Sbirna, L. S.; Sbirna, S.; Lepadatu, C. I.; Muresan, N.; Acta. Chim. Slov. 2001, 48, 439.

41. Borgo, C. A.; Ferrari, R. T.; Colpini, L. M. S.; Costa, C. M. M.; Baesso, M. L.; Bento, A. C.; Anal. Chim. Acta 1999, 385, 103.

42. Gushikem, Y.; Rosatto, S. S.; J. Braz. Chem. Soc. 2001, 12, 695.

43. Zaldivar, G. A. P.; Gushikem, Y.; J. Electroanal. Chem. 1992, 337, 165.

44. Kubota, L. T.; Gushikem, Y.; J. Electroanal. Chem. 1993, 362, 219.

45. Ju, H.; Gong, Y.; Zhu, H.; Anal. Sci. 2001, 17, 59.
46. Coutinho, C. F. B.; Coutinho, L. F. M.; Mazo, L. H.; Quim. Nova 2009, $32,228$.

47. Wen, X-L.; Jia, Y-H.; Liu, Z-L.; Talanta 1999, 50, 1027.

48. Zheng, J.; Zhou, X.; Bioelectrochemistry 2007, 70, 408.

49. Gilbert, O.; Chandra, U.; Swamy, B. E. K.; Char, M. P.; Nagaraj, C.; Sherigara, B. S.; Int. J. Electrochem. Sci. 2008, 3, 1186.

50. Pandurangachar, M.; Swamy, B. E. K.; Chandrashekar, B. N.; Sherigara, B. S.; Int. J. Electrochem. Sci. 2009, 4, 1319.

51. Ke, N. J.; Lu, S-S.; Cheng, S-S.; Electrochem. Commun. 2006, 8, 1514.

52. Yi, S.; Chang, H.; Cho, H.; Park, Y. C.; Lee, S. H.; Bae, Z.; J. Electroanal. Chem. 2007, 602, 217.

53. Kim, Y-R.; Bong, S.; Kong, Y-J.; Yan, Y.; Marajan, R. K.; Seung, K.; Kim, H.; Biosens. Bioelectron. 2010, 25, 2366.

54. Gelbert, M. B.; Curran, D. J.; Anal. Chem. 1986, 58, 1028. 